\title{
The Effect of TPSq and TPS Strategy on Students' Speaking Skill Viewed from Students' Motivation
}

\author{
HILMA PAMI PUTRI \\ English Department, IAIN Bukittinggi, West Sumatera, Indonesia \\ E-mail: mrs.bentama@gmail.com
}

\begin{abstract}
This research was aimed to investigate the effect of think pair square and think pair share strategy on students' speaking skill of describing things viewed from students' motivation. This research employed $2 \times 2$ factorial design and involved the students of SMK YPM Zain Pauh Kambar, Padang Pariaman. The samples were chosen by using purposive sampling. The data were gained through speaking test and analysed by using appropriate quantitative methods. The result of the research showed that think pair square and think pair share strategy were able to improve students' speaking skill. There was an interaction between teaching strategy and students' motivation of speaking skill. Hence, it can be concluded that these two strategies can be used as alternative strategies to enhance students' speaking skill, and that they can enrich students' experience to do other cooperative learning strategies.
\end{abstract}

Keywords : Think pair square strategy; think pair share strategy; students' motivation; students' speaking skill

\section{INTRODUCTION}

Any student who learns a language must be able to communicate in that language in terms of spoken or written language. Through the spoken or written language, the students are able to share their ideas, communicate with other people who speak that language, get a lot of friends, and more. Therefore, English teacher should provide a lot of opportunities for the students to communicate in English. For vocational school students, for example, the fluency in speaking is required, since the vocational school students are prepared to professional world. After graduated from vocational school, the students must have good speaking skill to compete with others in order to be employed in the job field. It is becomes one of the challenges for the teachers to help the students to improve their speaking skill. To achieve this goal, vocational school has developed a communicative approach in its language teaching. Therefore, the teachers should provide class activities in terms of real life communication.

The researcher focused on grade $\mathrm{X}$ of SMK YPM Zain Pauh Kambar. It was because of in that grade, the students were introduced to various kinds of the materials in learning English. One of them was describing things. In addition, the materials provided in grade $\mathrm{X}$ were bunches for the national examination, which was $40 \%$. The other reason was the students' mark on the semester test was very low. Only a few of the students achieved the minimum standard of the score.

These situations led the researcher to investigate the students and also the teacher in that school. Based on the researcher's experience in teaching English at SMK YPM Zain Pauh Kambar it was found that the students had difficulty to speak, or reluctant to speak. It was caused by several problems. The problem can be caused by internal and external factors of the students. Due to the facts, the researcher would like to create various experiences that enable students develop their speaking skills. One of the ways to increase students' speaking skill in the classroom is by applying cooperative learning, which would not be far from the communicative approach.

The cooperative learning enables students to work collaboratively with their friends to exchange information, and emphasizes the interaction of the 
students. This technique is divided into several strategies. The strategies are make a match, think pair share, think pair square, numbered head together, structured numbered head, jigsaw, etc. Among those cooperative learning strategies, the researcher would like to focus on think pair share and think pair square strategies as the way to solve these problems.

In think pair share strategy, the students have longer time to do their task, listening to their friends, and involve in a group. The teacher gives the students opportunity to work alone, and work together with others. Simply, it is designed to influence the students' interaction to help each other in a group of two. Based on Handayani (2012, p. 6), there are five steps of think pair share strategy, they are; orientation, thinking, pairing, sharing, and giving reward. After all the students get involved in the discussion process, the teacher gives the reward for the students individually and group.

While in think pair square strategy, the opportunity is given twice for students to share their ideas. Each couple was doing discussion. If one of the couple could not solve the problem or answer the question, the other couple will help. Based on Lie $(2007$, p. 57) there are six phase of think pair square strategy, which is little bit longer that than think pair share strategy. They are orientation, thinking, pairing, squaring, and sharing, and giving reward to the students individually and group to motivate the students to do better in the next meeting.

\section{METHOD OF THE RESEARCH}

This research was conducted by using quasi experimental research. It employed factorial design. The purpose of this design was to determine whether the effects of independent variable were generalizable across all levels or whether the effects were specific to particular levels. It was categorized as quantitative research, which is testing a theory of variables, measuring by numbers, and analyzing by using statistical techniques.

This research was aimed to find out the significance of think pair share and think pair square in teaching speaking. Therefore, there were two experimental groups used by the researcher here. First, the group which was taught by using think pair share strategy. Second, the group which was taught by using think pair square strategy. Both of the groups were given post test after they receive different treatments to see whether the groups show the differences and the effectiveness of the treatment.

The population of this research was grade $\mathrm{X}$ students in SMK YPM Zain Pauh Kambar. There were 134 students who were separated in six parallel classes. The researcher did cluster random sampling to choose the experimental class. Therefore, there were two groups that were involved in this research, class B and class C.

Test of speaking skill and the questioner were the instruments in this research used to collect the data about students' speaking skill. The form of the test was an oral performance test in form of presentation for both of the experimental. The students were asked to describe the simple object for about three to five minutes for each student.

Before analysing the hypothesis testing, the researcher needed to see the normality and the homogeneity of the data. The normality of the data could be analysed by using Lilliefors formula. Then, the homogeneity of the data can be seen trough $\mathrm{F}$ test formula. At last, the researcher could continue to analyse the hypothesis testing to answer the result of the research by using two ways ANOVA.

\section{FINDINGS}

There were four hypotheses in this research to answer the research questions. The hypotheses were:

\section{A. First Hypothesis}

The first hypothesis was tested by using $\mathrm{t}$ test with the significant level : 0.05 . The value of $t$ score was compared with the value of $t$ table. From the data analysis, it was found that think pair square strategy produces the same gain as think pair square strategy on students' speaking skill of describing things. For further description, it can be seen in the following table:

TABLE I.

The SUMMARY of the FIRST HYPOTHESIS

\begin{tabular}{|c|cc|cc|}
\hline \multirow{2}{*}{ Criteria } & \multicolumn{4}{|c|}{ Strategies / Classes } \\
\cline { 2 - 5 } & \multicolumn{2}{|c|}{$\begin{array}{c}\text { Think pair } \\
\text { square }\end{array}$} & \multicolumn{2}{c|}{$\begin{array}{c}\text { Think Pair } \\
\text { share }\end{array}$} \\
\hline Data & $N$ & 24 & $N$ & 24 \\
& $X_{1}$ & 79.17 & $X_{2}$ & 75.33 \\
& $S_{1}^{2}$ & 10.94 & $S_{2}^{2}$ & 9.70 \\
\hline$t_{\text {calculated }}$ & \multicolumn{4}{|c}{1,28} \\
\hline
\end{tabular}




\begin{tabular}{|c|c|}
\hline$t_{\text {table }}$ & 2,012 \\
\hline Conclusion & Not significantly different \\
\hline
\end{tabular}

The table above shows that first hypothesis was tested by using t-test with the significance level 0.05 . The value of $t$ obtained was compared with the value of $t$ table. It was found that table at the significant level : 0.05 is ' 2,012 ' while $t$ calculation's score is 1.28 . It can be concluded that $\mathrm{Ho}$ is accepted and $\mathrm{Ha}$ is rejected. It means that think pair square strategy produces the same gain as think pair square strategy on students' speaking skill of describing things.

\section{B. Second Hypothesis}

The second hypothesis was found that think pair square strategy produces better gain than think pair share strategy on students speaking skill for high motivation students. For further description, it can be seen from the table below:

TABLE II

The SUMMARY of the SECOND HYPOTHESIS

\begin{tabular}{|c|c|c|}
\hline \multirow[t]{2}{*}{ Criteria } & \multicolumn{2}{|c|}{ Strategies / Classes } \\
\hline & $\begin{array}{c}\text { High } \\
\text { motivation of } \\
\text { square class }\end{array}$ & $\begin{array}{c}\text { High } \\
\text { motivation of } \\
\text { share class }\end{array}$ \\
\hline \multirow[t]{3}{*}{ Data } & $N 6$ & $N 6$ \\
\hline & $X_{1} 81,33$ & $X_{2} 80$ \\
\hline & $S_{1}^{2} 13,85$ & $S_{2}^{2} 13,44$ \\
\hline$t_{\text {calculated }}$ & \multicolumn{2}{|c|}{2.27} \\
\hline$t_{\text {table }}$ & \multicolumn{2}{|c|}{2.17} \\
\hline Conclusion & \multicolumn{2}{|c|}{ significantly different } \\
\hline
\end{tabular}

The table above shows that the second hypothesis was tested by using t-test with the significance level 0.05 . The value of $t$ calculated was compared with the value of $t$ table. It was found that the score of $t$ table at the significance level 0.05 is 2.17 while the score of $\mathrm{t}$ calculated is 2.27. It meant that $\mathrm{t}$ calculated is bigger than table. It can be concluded that $\mathrm{Ha}$ is accepted. It means that Think pair square strategy produces better gain than think pair share strategy on students' speaking skill of describing things for high motivation students.

\section{B. Third Hypothesis}

The third hypothesis was found that think pair share strategy produced better gain than think pair square strategy on students' speaking skill for low motivation students. The test is conducted with t- test by considering number of students, mean, and variance between two groups. For further description, it can be seen from the table below:

TABLE III

The Summary of the Third Hypothesis

\begin{tabular}{|c|c|c|}
\hline \multirow{2}{*}{ Criteria } & \multicolumn{2}{|c|}{ Strategies / Classes } \\
\cline { 2 - 3 } & $\begin{array}{c}\text { Low motivation of } \\
\text { square class }\end{array}$ & $\begin{array}{c}\text { Low motivation of } \\
\text { share class }\end{array}$ \\
\hline Data & $N 6$ & $N 6$ \\
& $X_{1} 69,33$ & $X_{2} 67,33$ \\
& $S_{1}^{2} 7,33$ & $S_{2}^{2} 6,53$ \\
\hline$t_{\text {calculated }}$ & \multicolumn{2}{|c|}{2.19} \\
\hline$t_{\text {table }}$ & \multicolumn{2}{|c|}{2.17} \\
\hline Conclusion & \multicolumn{2}{|c|}{ Significantly different } \\
\hline
\end{tabular}

The third hypothesis was tested by using t-test at the significant level 0.05 . The value of $t$ calculated was compared with the value of $t$ table. It was found that $\mathrm{t}$ table at the significance level 0.05 is 2.17 while $t$ calculated is 2.19 . It can be concluded that $\mathrm{Ha}$ is accepted. It means that Think pair share strategy produced better gain than think pair square strategy on students' speaking skill of describing things for low motivation students.

\section{The Fourth Hypothesis}

The fourth hypothesis was used to find out the interaction between think pair share strategy and think pair square strategy. In this research, the researcher used ANOVA 2x2 formula in analysing the interaction between both of the strategy and the students' speaking skill (high and low motivation students). The result of analysis can be seen on the following table:

TABLE IV

The SUMMARY of the FOURTH HYPOTHESIS

\begin{tabular}{|l|c|c|c|c|c|}
\hline \multicolumn{1}{|c|}{ Variance } & Total $(\mathrm{JK})$ & $\mathrm{df}$ & $\begin{array}{c}\text { Average } \\
\text { Square }\end{array}$ & $\mathrm{F} \mathrm{h}$ & $\mathrm{F} \mathrm{t}$ \\
\hline $\begin{array}{l}\text { In row } \\
\text { (factor A) }\end{array}$ & 1.39 & 1 & 1.39 & 0.2 & 7.24 \\
\hline $\begin{array}{l}\text { In column } \\
\text { (factor B) }\end{array}$ & 11.02 & 1 & 11.02 & 1.60 & 7.24 \\
\hline $\begin{array}{l}\text { Interaction } \\
\text { (factor AB) }\end{array}$ & 2.45 & 1 & 2.45 & $\mathbf{0 . 3 6}$ & 7.24 \\
\hline In group & 303.45 & 44 & 6.90 & & \\
\hline
\end{tabular}

The third row in the ANOVA table above shows that the F calculated score is 0.36 and the score of the $\mathrm{F}$ table is 7.24. It can be concluded that $\mathrm{F}$ calculated $\leq$ than $\mathrm{F}$ table, it means that $\mathrm{Ho}$ is 
accepted. It can be said that there is no interaction between think pair share strategy and think pair square strategy to the students' initial achievement in students' speaking skill.

\section{DISCUSSION}

1. Think pair square strategy produces the same gain as think pair share strategy on students speaking skill of describing things.

The process of treatment in both of the classes was preceded in think pair square strategies and think pair share strategies on students' speaking skill of describing things. From the mean score of the students speaking skill of the square class and the share class were not significantly different. The mean score of the students in square class was 79.19 , and the mean score of the share class was 75.33. The data indeed that statistically both of the strategies produce the same gain on students' speaking skill. In other words, the result found that square class and the share class did not have significant different result in all categories computation. However, the mean score told that the think pair square class produces better gain on students' speaking skill of describing things.

The result of hypothesis testing 1 showed that the think pair square strategy give the same gain as think pair share strategy on students' speaking skill of describing things. There are several possible explanations for the same gain of the result; think pair square produces the same gain as think pair share strategy on students' speaking skill. First, the limited time of the treatment; the period of implementation may not sufficient to produce the desired effects. It is possible that students in both of the experimental group needed more time and training to master the skills for implementing the think pair square and think pair share strategy. The researcher just explained the rules of think pair share and think pair square strategy to the students right after the researcher take the pre test for the students in speaking. It made the students little bit confused with the rules because it was the first time for the students get this strategy in studying English. This is supported by Slavin (1995) that cooperative learning strategy need periods of training before starting to implement it in the classroom. The researcher realize that the researcher never apply these two strategies before, and just start to implement it in research right after reading the theories about the cooperative learning especially think pair square and think pair share strategy. Despite the teacher had explain the rules of the think pair square and think pair share strategy at the first meeting, the students apparently confuse with the rules or the procedures of the strategies for several meeting.

The other reason for this gain was the absences of the students influenced the result of the research. In every meeting, almost none of the students were absence, it also include on their late to come to class. These situations forced the researcher not divided the group proportionally based on the rules of the strategies. It also impact to the concentration of the students during the discussion.

Another reason for this gain is these two strategies are included in cooperative leaning strategy especially on informal method. Some of the other experts mention think pair share and also square at once. It is because of think pair square is the continuation of the think pair share strategy. The difference appeared on the number of the groups and also the square phase on the think pair square strategy. When the students could not get the answer of the questions on the pair phase, the students come to the square phase to get deep understanding or get the desired answer. Hence, these two strategies are close each other, and would affect to the same gain statistically.

The researcher wouldn't see this result as the failure, however these two strategies have been successful in helping students to learn academically and support each other. It is supported by Johnson and Holubec (1993, p. 94) conclude that "the elements of cooperative learning are positive interdependence, face to face interaction, individual and group accountability, and interpersonal and small group skill". These basic elements are structuring into group learning situations to ensure cooperative efforts and enable the implementation of cooperative learning for long term. The benefits of small group are many. Some include reducing the learning anxiety, the students become a team player, and the students participate in peer tutoring, building cooperative teams. In classroom discussion, the students try to help the other friend to fulfill the task given by the teacher. It makes the students fell comfort to reply the teacher, and they do not need to feel worry that the other friend will look down to him/her because they already have ideas on their mind. 
These finding is also closely related Michiel (2008, p. 146) who stated that the use of small group work and pair work activities can turn the students into positive learning experience because both of small group work and pair work increase students' talking time, allow mimic real English conversation, create a more secure and positive classroom atmosphere.

However, even though these two strategies produce the same gain on students' speaking skill of describing things, the result also show that these two strategies are also the same excellent strategies on students' speaking skill, not the same bad strategies on students speaking skills. In conclusion, both think pair square and think pair share are balance to make the students more motivated to speak up. It is supported by Zakaria (2012, p. 14) who states that cooperative leaning are great technique to allow the students work together not only for speaking skill, but also for the other skills such as listening, reading, and also writing.

2. Think pair square strategy produces the same gain as think pair share strategy on students' speaking skill of describing things for lower half student

It has been mentioned previously that think pair square produces the same gain as think pair share strategy on students' speaking skill of describing things. Actually, the lower achievement students get benefit from working in pair or group academically trough practice and communication. The students work together and help one other together. It is can be achieved through think pair share and think pair square strategy. For example, from the procedures of the think pair square itself; it can raise the students' consciousness to speak up to help their friend in solving the problem. Besides, in think pair share, the students also have chance to contribute meaningful discussion based on the material given to them.

For lower achievement students, the advantages of think pair square and think pair share strategy include a higher possibly of engaging individual learning style, increase the students' chance to be active in language use and greater variety types of language of students. Lower achievement students are often benefits from working in pairs and groups academically through practice and communication when the students help one another to work together. It can be achieved through the composition of pairing and grouping since the formation of these two types consist of higher and lower achievement. Sert (2005, p. 10) found that a variety of advantages of students collaboration in preparing written work since outputs are far more grammatical, include less spelling mistakes, and indicate a higher level of grammatical awareness.

Pellowe (1996, p. 3) claimed that the students can work properly in pairs and groups. In order to complete a task assigned by the teacher, students in pairs or group must negotiate in order to complete the task, find the correct work and determine the best way to complete the task. When students have freedom to negotiate the meaning and the form of what they are saying, it will lead the students to the specific areas of their language that need development. attitudes toward

Generally, Schul (2012, p. 2) claims that both high and low achievers in cooperative learning treatment are usually perform better and have positive attitudes toward grouping than working individually. He adds that the way of cooperative learning like think pair share and think pair square can success to ensure that all of the groups member's activity are focus on explaining concept to one another, helping one another to practice, and encouraging one another to achieve. Thus, the effect of cooperative learning on students' speaking skill would be wider. There is one evidence prove that group processing activities can enhance the effect of cooperative learning.

3. Think pair share strategy produces the same gain as think pair square strategy on students' speaking skill of describing things for upper half students

According to the description of the data above, it could be concluded that think pair share strategy produces the same gain as think pair square strategy on students' speaking skill of describing things for upper half students. Referring to the finding, the Association for Educational Communication and Technology (2001) declared that high achieving students benefit by the cognitive restructuring that occurs when providing in-deepth explanation to peers. Moreover, cooperative learning works best in groups of two to five students (Ulmer and Cramer, 2005). Here, the students must take accountably not only to the group but also be responsible for their 
own learning. Positive interdependence can be developed through individual and group accountability. For cooperative learning to be effective, it is important that students work together to learn material but be tested individually. This is the art of creating positive interdependence. To complete the process the teacher recorded the groups' average test score as an individual student's grade. The accountability is created in two ways: first all team members must do well for themselves, and second, they must do well for the group. It becomes the common goal of the group for everyone to do well on the assessment in order to obtain a higher overall grade.

Generally, Brophy (2000,p. 18) claimed that students often benefit from working in pairs or small groups to construct understandings or help one another master skills. Moreover, he explained that there is often much to be gained by arranging for students to collaborate in pairs or small groups as they work on activities and assignments. Cooperative learning promotes affective and social benefits such as increased student interest in and valuing of subject matter, and increases in positive attitudes and social interactions among students who differ in gender, race, ethnicity, achievement levels and other characteristics. Co-operative learning also creates the potential for cognitive and metacognitive benefits by engaging students in discourse that requires them to make their taskrelated information- processing and problemsolving strategies explicit (and thus available for discussion and reflection).

4. There is no interaction between think pair square strategy and think pair share strategy to students' initial achievement on students speaking skill of describing things.

Based on the hypothesis testing, it showed that the students' speaking skill of describing things who were taught by using think pair square and think pair share strategy were not influenced by their initial achievement. It means that upper half students and lower half students who were taught by using think pair square and think pair share strategy would not improve their speaking skill. Shortly, the dependent variable was not affected purely by the independent variable, nor the moderator variable.
Solomon (2009, p. 73) stated that the level of students' initial achievement that use cooperative learning will contribute positively to learning outcome for both lower and upper achievement. Similar to the previous opinion, Slavin (2009, p. 38) explained that the interaction between the students and learning progress will happen simultaneously in developing students' learning achievement. This due to both pairing and squaring has responsibility being counted individually and grouped. It means that high and low achievement will support each other to learn together in learning knowledgeable students to start high and low support each other to obtain the best result for their group.

As a whole, the effect of cooperative learning toward the students' ability on students' ability is exactly gain positive result. In other words, any levels of initial achievement students who used cooperative learning strategy such as think pair share and think pair square will contribute positively to the students' speaking skill either for high and low initial achievement students. Thus, the high and the low achiever students will support each other to learn together and obtain the best result of their group.

\section{CONCLUSIONS}

The researcher had afforded to conduct better research to reach maximum research. However, the researcher realized that there are several limitations of the research, such as:

1. This research was only conducted in speaking skill of describing things at grade $\mathrm{X}$ SMK YPM Zain Pauh Kambar. Therefore, it could not be treated on the other learning material or even other genres of text.

2. There was also limited time for teaching think pair square and think pair square in the classroom. Both of the teacher and the students just new to both of the strategies. It makes both of the students and teacher did not really master in applying these strategies in the classroom.

The absences of the students influence the group of discussion in every meeting, and impact to the result of the speaking test.

\section{SUGGESTION}

In accordance with the conclusion and implication above, the researcher provides suggestions as follow: 
1. The students are suggested to apply the think pair square and think pair share strategies in other suitable material to reduce their anxiety, become a good team, and build the cooperative team. The study showed that both think pair square and think pair share strategies are equally powerful in improving students' speaking skill of describing things.

2. The teacher should plan carefully in planning the activities for teaching and learning process by using think pair square and think pair share strategy.

3. Other researchers who are interested in carrying out the research in applying the think pair square and think pair share strategies are suggested to conduct the similar research in wider sample in order to get larger empirical data and knowledge. Besides, they are also suggested to consider the research finding because these two strategies still need adjustment between the strategies and the other factors such as the other skills, and the other materials.

\section{ACKNOWLEDGMENT}

I would like to express my deepest appreciation to all those who provided me the possibility to complete this journal. A special gratitude I give to the persons who gave scientific guidance, the suggestions and encouragement in writing this journal.

\section{REFERENCES}

[1] Dewantara, I.P.M. (2012). Model Pembelajaran Kooperatif Tipe ThinkPair-Square.Denpasar: Universitas Pendidikan Ganesha.

[2] Johnson, D.W., Johnson, R. T \& Holubec, E. J. (1993). Cooperation in the classroom $\left(6^{\text {th }} \mathrm{Ed}\right)$. Edina, MN: Interaction Book Company.

[3] Lie, A. (2002). Cooperative Learning Mempraktikkan Cooperative Learning di Ruang- Ruang Kelas. Jakarta: PT. Gramedia Widiasarana Indonesia.

[4] Michiel, B. (2008). Helping Behavior during Cooperative Learning and Learning Gains: the Role of the Teacher and the Pupils' Prior Knowledge and Ethnic Background. Learning and Instruction Jurnal, Volume 18, issue 2, April. Faculty of Social and Behavioral Sciences, Leiden University.

[5] Pellowe,W. R. (1996). Modifying Pair Work Activities to Encourage the Use of English and Communication Strategies: An Action Research Project, ELTED Journal Vol. 2 Issue 1. Retrieved from http://www.elted.net/issues/volume-2/pellowe.pdf on 1st June 2013.

[6] Schul. J. E. (2012). Revisiting and old friend.: the practice and promise of cooperative learning for the twenty first century. The social studies, / 102 , 88-93. Retrieved from http://www.social studies.cooperative laearning.htm. at Decxember $8^{\text {th }} 2012$

[7] Sert. O. (2005). A Comparative Analysis of Pair Work and Individual Assignment in Two ELT Grammar Classes. Journal of Language and Linguistics Studies Vol 1, No 2. Retrieved from http://www.eric.ed.gov/PDFS/ED496120.pdf. on 1st of June 2013.

[8] Slavin, R.. E. (2005). Cooperative Learning ( $\left.2^{\text {nd }} e d\right)$ New York: Allyn and Bacon.
[9] Solomon, S. (2009). Cooperative Learning Theory: Research and Practice. Chicago: Allyn and Bacon.

[10]Zakaria, E. C. L \& Daud, Y. (2000). The Effect of Cooperative Learning on Students' Mathematics Achievement. \& Attitude toward Motivation. Jurnal of Social Science. Vol. $2 . \quad 272-275$. http//dx.doi.org/10.3844/jssp.2010.272.275. 